\title{
Karakteristik Bahasa Arab
}

\author{
Ahmad Feby Febryan Fakaubun \\ Sekolah Tinggi Agama Islam Negeri (STAIN) Sorong, Papua Barat, Indonesia \\ Email : ahmadfakaubun12@gmail.com
}

\begin{abstract}
ABSTRAK
Secara umum bahasa adalah alat untuk berinteraksi atau berkomunikasi yang berupa lambang bunyi yang dihasilkan alat ucap manusia, untuk dapat menyampaikan pikiran, gagasan, konsep atau perasaan seseorang. Bahasa juga terdiri atas beberapa kata yang apabila digabungkan akan menjadi makna tersendiri. Bahasa arab merupakan bahasa resmi bangsa arab. selain menjadi bahasa agama muslim di seluruh penjuru dunia, bahasa arab juga digunakan sebagai bahasa Al-qur'an yang merupakan kitab suci umat islam. Dan bahasabahasa sempit termasuk bahasa arab memiliki watak linguistik triliteralitras, yaitu : kata- katanya terdiri dari akar tiga kosonan dan derivsatif dari akar ini.
\end{abstract}

\section{Pendahuluan}

Bahasa adalah alat untuk berinteraksi atau berkomunikasi. Bahasa diciptakan sebagai alat komunikasi universal yang diharapkan dapat dimengerti oleh setiap manusia untuk melakukan suatu interaksi yang diharapkan agar dapat dimengerti oleh setiap umat muslim atawpun setiap manusia untuk melakukan suatu interaksi sosial dengan manusia lainya. Dan bahasa juga sistem lambang bunyi yang arbitrer, yang dipergunakan oleh para anggota suatu masyarakat untuk bekerja sama, berinteraksi, dan mengindentifikasi diri, percakapan (perkataan) yang baik, tingkah laku yang baik, sopan santun, baik budinya, atau perangai serta tutur kata menujukkan sifat dan tabiat seorang (baik burukya kelakuan menunjukkan tinggi rendah asal atau keturunan).

Bahasa arab merupakan Semit Tengah yang merupakan rumpun dari bahasa semit, dan berkerabat dengan bahasa ibrani dan bahasa-bahasa Neo Arami. Bahasa arab memiliki lebih banyak penutur daripada bahasa-bahasa lainya dalam rumpun bahasa semit. Ia dituturkan oleh lebih dari 280 juta orang sebagai bahasa pertama, yang mana sebagian bahasa pertama, yang mana sebagian berasal dari timur tengah dan afrika utara. Bahasa ini adalah bahasa resmi dari 25 negara, dan merupakan bahasa peribadatan dalam agama islam 
karena merupakan bahasa yang dipakai atau digunakan sebagai bahasa dalam membaca Al'qur-an.

\section{Karakteristik Bahasa Arab}

Secara umum bahasa adalah alat untuk beriteraksi atau berkomunikasi berupa lambang bunyi yang dihasilkan alat ucap manusia, untuk menyampaikan pikiran, gagasan, konsep atau perasaan seseorang. Bahasa terdiri atas kumpulan kata yang apabila di gabungkan akan memiliki makna tersendiri. Bahasa diciptakan sebagai alat komunikasi universal yang diharapkan dapat dimengerti oleh setiap manusia untuk melakukan suatu interaksi sosial dengan manusia lainnya.

Bahasa arab merupakan Bahasa resmi bangsa Arab. Selain menjadi Bahasa orang muslim di seluruh penjuru dunia, Bahasa Arab digunakan sebagai Bahasa Al-qur'an yang merupakan kitab suci umat islam. Setiap Bahasa memiliki karakteristik masing-masing yang berbeda dengan Bahasa lain yang membedakan setiap Bahasa menjadi unik dan memiliki ciri khas. Bahasa Arab mempunyai ciri-ciri kekhususan yang tidak terdapat pada bahasa-bahasa lainnya. Kemudian dari kekhususannya ini menjadikan bahasa Arab sebuah bahasa yang fleksibel, mempunyai elastisitas yang tinggi, maka dalam menjalankan dan mempertahankan fungsinya sebagai bahasa komunikasi, sarana dalam penyampaian tujuan agama, pencatatan berbagai ilmu pengetahuan, telah mampu disampaikan dengan mudah dan benar.Berikut ini adalah yang merupakan keistimewaan bahasa Arab, antara lain :

\section{Isytiqaq}

Yang dimaksud dengan isytiqoq adalah pengambilan sighot (bentuk kata) dari sighot yang lain, karena ada persamaan baik dari segi bentuk, maknanya maupun strukturnya dengan beberapa tambahan tertentu yang telah ditetapkan.

Ada dua pendapat ulama mengenai isytiqok ini, antara lain :

1. Ulama Bashrah bahwa sumber isytqoq adalah masdar

2. Ulama Kufah bahwa sumber isytiqaq adala kata kerja (fi ’il).

Isytiqoq menurut ulama bahasa di bagi tiga macam, antara lain: 
1. Isytiqoq shogir yang aplikasinya melalui tasrif yang kita kenal selama ini yaitu pengembangan lafadz dari lafadz asli dengan syarat adanya kecocokan dari segi makna, huruf dan juga urutannya. Contohnya:

ضرب - ضارب - مضروب

2. Istiqoq kabir disebut juga al-qalb al-luqhawi, yaitu adanya persamaan antara dua kata, baik dari segi lafadz maupun dari segi makna, akan tetapi tidak sama dalam urutan huruf sebagai contoh :

حمد - مدح / جبد - جدب

3. Isytiqoq Akbar disebut juga al-ibdal al-liqhawi, yaitu menukar suatu huruf yang lain. dalam proses ini huruf yang mengalami pertukaran tidak disyaratkan memiliki makhroj yang sama. Boleh saja terjadi pada setiap hurufkarena yang penting disini adanya kesesuaian makna antara dua lafadz, contoh:

السراط - الصراط

Yang memiliki makna suatu dengan dua lafadz yang berbeda. Isytiqoq al-Kibar atau an-naht (penyingkatan). An-Naht adalah membuat kata baru yang ambil dari dua unsur kata yang berbeda atau lebih tetapi tetap menunjukan pada makna yang diambil baik berupa isim dan fi'il. Perkembangannya harus sesuai dengan kaidah (wazan) bahasa arab yang terdapat dalam tashrif, sebagai contoh :

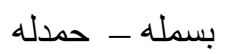

\section{Ta’rib (arabisasi)}

Yang dimaksud dengan ta rib disini yakni kata asing yang diambil kedalam bahasa arab, dalam proses ta rib mungkin terjadi pengurangan, penambahan penukaran sehingga bahasa tersebut menjadi bahasa arab asli sebagai contoh dari kata yang terdapat penambahan dan penukaran : kata (kulit hitam) berasal dari bahasa Persia ditambah alif dan ha ditukar dengan huruf jim.

ارندج -رند

\section{Al-Irab}


Keistimewaan bahsa Arab juga disebabkan kehadirannya I'rab, bahkan dapat dikatakan bahwa I’rab adalah ciri khas bahasa arab. I'rab adalah perubahan bunyi akhir suatu kata dalam kalimat yang disebabkan oleh perbedaan factor ('amil yang menyertainya, baik amil disebut itu jelas maupun diperkirakan dalam benak') Perbedaaan tersebut dapat mempengaruhi makna'.

Efek yang di timbulkan terhadap karakat, sebagai contoh :

هدا تلميد - رأيت تلميدا - مررت بتلميد

تكتب - لن تكتب - لم يكتب

Efek ditimbulkan terhadap jumlah sangat elastisitas.

أكل محمد السمك ـ السمك أكل محمد - محمد أكل السمك

علي يتعلم اللغة العربية - جاء ابوه - حضر المسامون

Dalam bahasa arab, ada dua gender maskulin dan feminine yang masing-masing mempunyai bentuk yang berbeda-beda, kata ejektif dan kata kerja. Bentuk-bentuk feminin menurut kaidahnya dibentuk dan kata-kata maskulin dengan menambahkan akhiran (atun /un). Dalam bahasa arab terdapat tiga bentuk bilangan yaitu : Tunggal, ganda dan jamak.

\section{Ilmu Balaghah}

Ialah ilmu yang mempelajari gaya bahasa dan rahasia-rahasia yang terkandung dalam bahasa arab, khususnya Al-Qur’an. Tegasnya ilmu balaghah ini merupakan ilmu kesustraan bahasa arab. Ilmu balaghah ini mengandung tiga pokok pembahasan :

علم المعاني - علم البيان - علم البديع

Ilmu bayan mengandung dua pokok pembahasan .

التشبية - المجاز ـالكناية

Ilmu Maani mengandung banyak pokok bahasan, antara lain :

الخبر والانشاء - الدكر والحدف ـالتقديج والتاخير - القصر - الوصل والفصل ـالايجاز والاطناب ـ المساواة

Ilmu badi` mengandung dua pokok pembahasan 
المحسنات المعنوية - المحسنات اللفظية

\section{Al-Mufrodat}

Setelah al-Qur'an turun, banyak pengertian atau arti kosakata yang mengalami pergeseran, perubahan makna semanti, seperti dalam contoh :

لا ريب فيه - لاشك / الصبح - الفجر/ قعد - جلس / زوج - امراة

Kata jauz dan imraah ditampilkan dalam konteks kehidupan suami istri yang penuh kasih sayang dan memiliki anak keturunan, sedangkan mempunyai makna istri yang dalam kehidupan suami istri tidak terdapat kasih sayang karena ada khianat/ perbedaan akidah dan digambarkan dalam surah yusuf $(12 ; 30 ; 51)$ dan surat at-Tahrim $(66 ; 10 ; 11)$. Lafal_lafal dalam al-Qur`an jika diperhatikan dan diteliti secara mendalam akan munculkan kajian baru, sehingga nantinya al-Qur`an bukan hanya sebagai sumber hukum islam antara fiqih dan akhidah tetapi juga merupakan sumber hukum.

Bahasa juga terdiri atas lambang-lambang, yaitu tanda yang digunakan untuk menyatakan sesuatu yang lain. Didalam bahasa, tanda terdiri dari rangkaian bunyi yang pada ragam tulis dialihkan kedalam tanda-tanda visual yaitu huruf dan tanda baca. Hubungan antara rangkaian bunyi tertentu dan makna yang dinyatakan bersifat arbiter semata tidak ada hubungan yang wajar antara lambang dan objek yang dilambangkannya (Panuti Sufirman, 1993, hal 9), Contoh :

Za`za`ah artinya goncangan

Qolqalah artinya keributan

Solsolah artinya bunyi berderek-derek

Qa`qa`ah artinya gemerincing

Jarjarah artinya bising

Qorqorah artinya keroncongan

\section{Al-Dalaalah}

Ilmu dalalah disepakati sebagai istilah yang digunakan untuk bidang linguistic yang memepelajari hubungan antara tanda-tanda linguistik dengan hal-hal yang ditandainya. 
Atau dengan kata lain, bidang studi linguistik yang mempelajari makna/ arti dalam bahasa arab mengenai jenis-jenis makna. Mukhtar umar membaginya kepada lima jenis

1. Al-Ma'na al-asasiy adalah makna kata yang melakat pada sebuah kata.

2. Al-Ma na al-ishafy adalah makna yang terkandung dalam sebuah kata disamping makna sebenarnya yang melekat pada kata tersebut.

3. Al-Ma`na al -ushuby makna yang berkenaan dengan gaya pemilihan kata didalam masyarakat sehubungan adanya perbedaan sossial, geografi tingkat pendidikan.

4. Al-ma na al-nafsy makna yang terkait pada orang tertentu tetapi tidak untuk umum.

5. Al-Ma na al-ihaiy maka yang terkandung dalam sebuah kata yang menunujukan kepada seseorang yang berkenaan adanya kata itu dengan keadaan diluar bahasa.

Dalam kajian ini ada lafal-lafal bahasa Arab yang dihubungkan dengan lafal-lafal lainnya dan dikaitkan dengan pemakaiannya dan kita kenal dengan sebutan at-taraduf almusytaraq lafdzhi dan at-tadhodz.

\section{Taraduf / sinonim}

Secara harfiah berarti sesuatu mengikuti sesuatu sedangkan kata taraaduf itu sendiri berarti sesuatu yang saling mengikuti. Secara etimologi definisi Taraduf menurut Dr. Taufik Muhammad Salim beberapa kata menunjukan arti yang sama. Contoh :

Zauj - imara`ah / As-subh - al-fajr

\section{Al-Musytarak - al-lafidziy}

Musytarak al - lafdziy dalam bahasa indonesianya adalah kata-kata yang sama bunyinya tetapi mengandung arti dan pengertian berbeda. Contoh:

Kata Syahaadah mengandung sepuluh arti/makna , antara lain : Observasi, menyaksikan, melihat, yakni, beraksi, DLL

\section{At- Tadhodz atau Antonim.}

Para ahli bahasa Arab mendefinisikan antonim dengan menggunakan satu kata untuk dua pengertian yang berlawanan seperti.

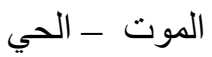


البياض - البيضناء

\section{Karakteristik bahasa arab}

Bahasa- bahasa sempit termasuk bahasa arab memiliki watak linguistik triliteralitas, yaitu : kata- katanya terdiri dari akar tiga konsonan dan derivatif dari akar ini. Dari akar tiga konsonan ini, kata di bentuk melaluiproses yang di sebut "konjungsi" atau "tasrif"yang tersdiri dari perubahan vokalisai tiga konsonan berdasarkan kaidah, penambahan satu atau lebih konsonan sebagai awalan, akhiran atau sisipan dan mengubah vokalisasi juga . misalnya : kata qola قال yang berarti "berkata " terambil dari huruf qaf ق , wau و , dan lam ل dari kata qala قال yang terdiri dari kata konsonan dapat dibentuk dari kata lain yang makannya berbeda, seperti muqawil مقاول bermakna kontraktor" kemudian di ubah menjadi waqola/yang bermakna satu kaki dan memantapkan kakilain ke bumi (shihab : 1997:94)

\section{fonetik arab}

fonetik arab memiliki tiga tempatkeluar huruf atau mahroj yaitu :
a. mahroj tenggorokan dan ujung tenggorokan hurufnya adalah : ا,و,ي,ح,ع,
b. kelompok huruf yang terletak pada lidah adalah ك,ق,ت,ج,ض,ري,ش,د,ز,ط,ن,ص
c. mahroj pada bibir hurufnya adalah

\section{Tata Bahasa Arab}

Selalu berinfleksi (berubah) menurut shihab (1997: 95) bahwa Bahasa Arab selalu mengubah akhir kata benda bergantung pada kasusnya, baik sebagau objekl langsung maupun tidak langsung dan mengubah akhir kata kerja bergantung keterangan waktu. Bunyi suatu kata yang berbeda mengakibatkan perbedaan arti yang sangat jauh. Sebagai contoh:

a. Ma ahsana al samai / ما أحسن السّماءartinya apa yang terindah di langit.

b. Ma ahsana al sama'a / ما أحسن السّماءartinya apa alangkah indahnya langit itu.

Dijelaskan oleh shihab (1997:95) bahwa sintaksis aranb sangat rasional dan seksama tetapi cukup rumit bila dibandingkan dengan bahasa Indonesia. Dalam tata Bahasa Arab dikenal ilmu shorof atau morfologi yaitu ilmu untuk menata bentuk kalimat. 
Macam-macam pola kata dalam Bahasa Arab antara lain : Fiil Madhi, Fiil Mudharik, Isim Faail, Isim Maful, Masdar (akar kata), isim makan, isim zaman.

\section{Kosakata Arab}

Kekayaan kosa kata tidak hanya terlihat pada jenis kelamin kata atau bilangannya yaitu mufrod (tunggal), mutsanna (dual) dan jamak (plural) tetapi pada kekayaan kosa kata dan sinonim sebagai contoh: cahaya memiliki 21 sinonim, matahari (29), onta (255), singa (350), ular (100), madu (80). Contoh : kata قَََََحَ dan sama-sama diterjemahkan duduk, tetapi pengguanaannya berbeda. (Ismail dan Nas Haryati S. 24:2008)

\section{KESIMPULAN}

Bahasa adalah alat untuk beriteraksi atau berkomunikasi berupa lambang bunyi yang dihasilkan alat ucap manusia, untuk menyampaikan pikiran, gagasan, konsep atau perasaan seseorang. Bahasa terdiri atas kumpulan kata yang apabila di gabungkan akan memiliki makna tersendiri. Bahasa diciptakan sebagai alat komunikasi universal yang diharapkan dapat dimengerti oleh setiap manusia untuk melakukan suatu interaksi sosial dengan manusia lainnya.

Bahasa arab digunakan sebagai bahasa Al-qur'an yang merupakan kitab suci umat islam.setiap bahasa memiliki karakteristik masing-masing yang berbeda dengan bahasa lain yang membedakan setiap bahasa menjadi unik dan memiliki ciri khas.bahasa arab memiliki cirri-ciri kekhususan yang tidak terdapat pada bahasa-bahasa lainnya.kemudian kekhususannya ini menjadikan bahasa arabsebuah bahasa arab yang fleksibel, mempunyai elastisitas yang tinggi, maka dalam menjalankan dan mempertahankan fungsinya sebagai bahasa komunikasi, sarana dalam penyampaian tujuan agama, pencatat berbagai ilmu pengetahuan, telah mampu di sampaikan dengan mudah dan benar.

\section{DAFTAR PUSTAKA}

Ismail, \& Haryati S, Nas. (2008). Studi Bahasa Arab dan Kata Serapan Bahasa Arab dalam bahasa Indonesia. Semarang: RUMAH INDONESIA 
Ahmad Fuad Effendi,(2004). Metodologi Pengakaran Bahasa Arab, Malang: Misykat.

Radliyah Zaenuddin dkk.,(2005). Metodologi dan Strategi Alternatif Pembelajaran Bahasa Arab, Yogyakarta: Pustaka Rihlah Group.

Hermawan Acep, (2011). Metodologi Pembelajaran Bahasa Arab, Bandung: PT Remaja Rosdakarya.

Matsna Moh, (2009). Karakteristik dan Problematika Bahasa Arab, dalam Jurnal Arabia Vol. I Nomor 1. 